\title{
Peningkatan Efektivitas Training Calon Operator Kamera TV Berbasis Aplikasi Android
}

\author{
Roni Sasongko ${ }^{1}$, Arief Setyanto ${ }^{2}$, Sudarmawan ${ }^{3}$ \\ ${ }^{1,2,3}$ Universitas Amikom Yogyakarta Jalan Ring Road Utara Condong Catur Depok-Sleman \\ 1) sasongko0606@gmail.com , ${ }^{2)}$ arief_s@amikom.ac.id, ${ }^{3)}$ sudarmawan@amikom.ac.id
}

\begin{abstract}
Abstrak
Penelitian ini bertujuan untuk memberikan rekomendasi aplikasi android yang efektif untuk program training calon operator kamera televisi, mengetahui tingkat efektifitas waktu yang dibutuhkan untuk proses training anggota baru stasiun televisi, mengetahui kualitas hasil training dalam segi pengetahuan maupun keterampilan dan memberikan alternatif proses training sehingga lebih mudah dipahami oleh anggota baru stasiun televisi.

Penelitian ini menggunakan anggota MMTC TV sebagai sample. Pengujian aplikasi mobile learning berbasis android menggunakan metode independent samples $t$ test guna mengetahui perbandingan aplikasi yang dapat memberikan tingkat efektivitas ter tinggi dari dua aplikasi yang diuji, yaitu aplikasi android berbasis teks dan berbasis audio. Pengujian tingkat efektifitas training calon operator kamera televisi dilakukan dengan menggunakan metode paired samples $t$ test. Pengujian dilakukan dengan melakukan pretest dan posttest. Pretest dilakukan sebelum calon operator kamera televisi menggunakan aplikasi android sedangkan posttest dilakukan setelah calon operator kamera televisi menggunakan aplikasi android.

Dari hasil pengujian dua aplikasi android berbasis teks dan audio, aplikasi berbasis teks mampu memberikan hasil yang lebih signifikan yang dibuktikan dengan pengujian independent sample $t$ test. Proses training calon operator kamera televisi dengan menggunakan aplikasi android terbukti lebih efektif yang di buktikan dengan uji paired samples t test dimana pengetahuan peserta training meningkat dan waktu yang dibutuhkan dalam proses training semakin singkat.
\end{abstract}

Kata kunci:Mobile learning, kamera televisi, android

\section{PENDAHULUAN}

Stasiun Televisi merupakan stasiun penyiaran yang menyebarkan siarannya dalam bentuk audio dan video secara bersama-sama yang akan di terima oleh pesawat televisi penerima. Stasiun televisi terbagi menjadi stasiun televisi komersial, telavisi non komersial, stasiun televisi publik, lokal dan nasional.

Dalam menjalankan fungsinya sebagai stasiun televisi, tentu saja stasiun televisi membutuhkan anggota yang dapat mengoperasikan, menginstall, menganalisa masalah sesuai dengan standard operasional prosedur (SOP). Oleh sebab itu stasiun televisi harus mempunyai anggota yang mempunyai kemampuan yang memadai dalam menjalankan fungsi dari stasiun televisi tersebut termasuk operator kamera.

Operator kamera atau yang sering disebut dengan Cameraman mempunyai peranan penting dalam proses pengambilan gambar pada stasiun televisi, dengan demikian seorang cameraman harus paham terhadap SOP, fungsi, maupun cara pengambilan gambar yang baik dengan menggunakan kamera.

Proses training anggota baru sangat penting maka stasiun televisi akan mempersiapkan proses training dengan sebaik-baiknya. Keberhasilan proses training akan sangat berpengaruh terhadap pemahaman maupun pengetahuan anggota baru yang tentu saja berpengaruh terhadap kinerja. Jika kinerja anggota televisi itu baik maka hasil output stasiun televisi juga akan lebih berkualitas.

Manajer akan memberikan pengarahan langsung dengan memberikan teori dan atau materi dalam proses training anggota baru televisi, kemudian manajer juga akan memperkenalkan peralatan yang digunakan dengan mengarahkan anggota baru ke studio. Dengan demikian masih dapat ditemukan kelemahan dari proses training tersebut, diantaranya adalah penguasaan materi dan penguasaan alat yang masih rendah. Hal ini 
disebabkan oleh beberapa kendala, menurut manajer MMTC TV kendala tersebut diantaranya, Anggota baru televisi sering lupa dengan fungsi tombol peralatan yang telah dijelaskan sebelumnya, jadwal pelatihan tidak menentu dikarenakan manajer juga mempunyai tanggung jawab yang lain sehingga waktu pelatihan kurang efektif, proses pelatihan membutuhkan waktu yang lama sehingga menghambat produktifitas dari stasiun televisi.

Berdasarkan permasalahan diatas, peneliti memandang perlu untuk dikembangkannya suatu media pembelajaran berbasis aplikasi mobile phone yang menggunakan elemen Multi Media yaitu video, audio, teks dan gambar, untuk mendukung proses pelatihan calon operator kamera televisi, guna meningkatkan efektivitas waktu training dan meningkatkan kualitas training calon operator kamera televisi.

Nasution, et. al. (2018) Meneliti tentang pengembangan media pembelajaran aplikasi Buku Saku Digital Komputer berbasis Android. Ujicoba dilakukan di STKIP Tapanuli Selatan oleh 30 siswa dan menunjukkan respon positif karena semua menunjukkan persentase $\geq 70 \%$. Berdasarkan data tersebut dapat disimpulkan bahwa media pembelajaran Aplikasi Komputer dikemas dengan menarik, contoh soal dan soal disampaikan dengan jelas, mendorong rasa ingin tahu dalam belajar Aplikasi Komputer., menambah pemahaman tentang Aplikasi Komputer., dan menambah motivasi dalam belajar Aplikasi Komputer.

Krisnawati dan Supari Muslim (2016) Penelitian ini bertujuan untuk mengembangkan dan menghasilkan media pembelajaran yang valid berbasis android pada mata pelajaran instalasi penerangan listrik di SMK Negeri 3 Surabaya. Selain itu, penelitian ini juga untuk menganalisis respon siswa terhadap penggunaan media pembelajaran berbasis android serta untuk menganalisis hasil belajar siswa terhadap penggunaan media pembelajaran berbasis android pada mata pelajaran instalasi penerangan listrik di SMK Negeri 3 Surabaya. Pengembangan media pembelajaran instalasi penerangan listrik ini memberikan dampak yang positif sehingga dapat meningkatkan motivasi siswa dalam belajar, selain itu media pembelajaran tersebut berakibat pada waktu pembelajaran yang menjadi lebih efektif dan efisien.

\section{METODE PENELITIAN}

Jenis penelitian yang akan dilakukan yaitu penelitian tindakan, peneliti akan melakukan penelitian pada MMTC TV dengan meneliti, mempelajari, merencanakan, mengambil tindakan, melakukan pengamatan dan memberikan suatu solusi dari permasalahan pada proses training calon operator kamera MMTC TV. Sifat dari penelitian ini akan ditunjukan dengan sifat deskriptif dimana hasil yang disajikan dalam bentuk angka yang dapat ditarik suatu kesimpulan dalam meningkatkan efektifitas training calon operator kamera televisi

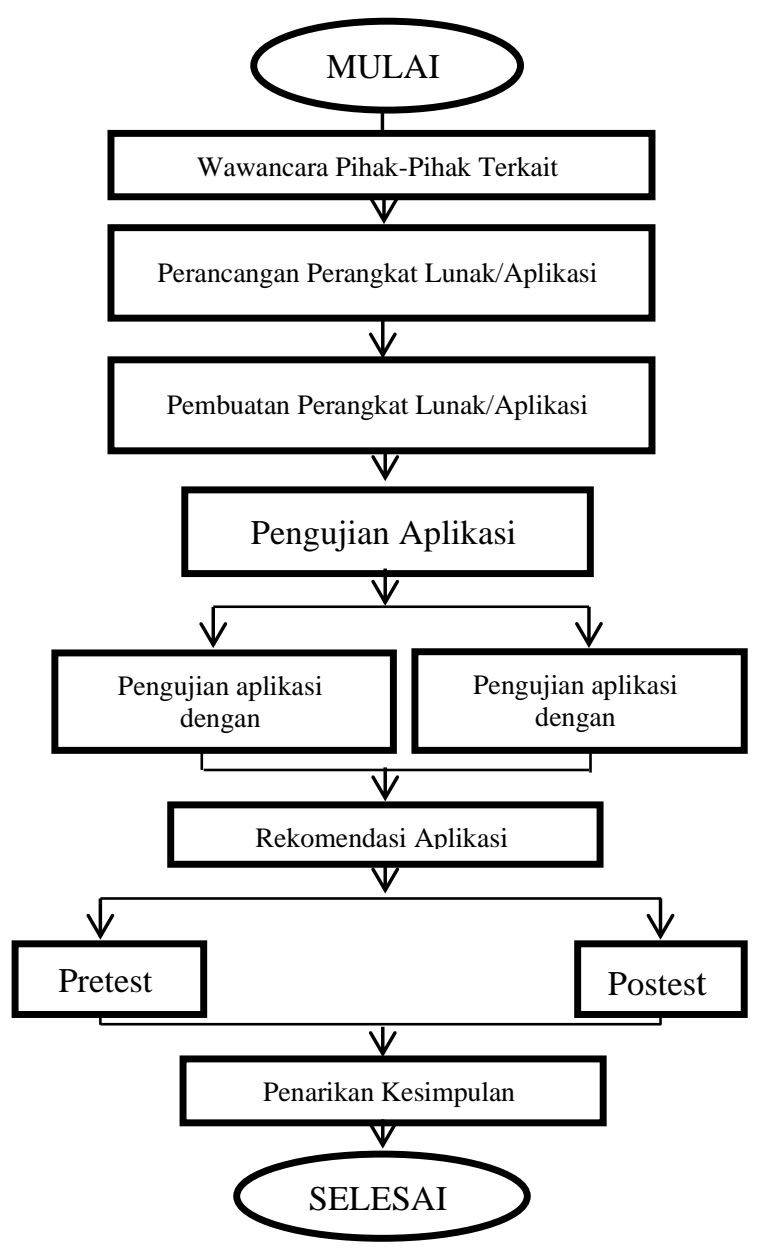

Gambar 1. Alur Penelitian

Gambar 1. menunjukan alur penelitian yang akan dilakukan, peneliti akan melakukan identifikasi perumusan masalah , dari identifikasi masalah yang ditemukan peneliti akan mencari kajian pustaka terkait dari masalah yang ditemukan dengan mencari 
referensi-referensi dari jurnal penelitian yang sesuai, buku, laporan penelitian maupun dari sumber lainnya . setelah mendapatkan kajian pustaka yang diinginkan peneliti mencoba mencari data MMTC TV sebagai data yang akan diteliti. Setelah mendapatkan data MMTC TV maka peneliti mulai mengambil data-data yang diperlukan dalam penelitian , setelah data yang di perlukan sudah ada maka langkah selanjutnya yaitu membuat aplikasi mobile learning dengan elemen multimedia teks dan audio. Setelah pembuatan aplikasi maka akan dilakukan pengujian terhadap aplikasi guna merekomendasikan aplikasi yang seperti apa yang nantinya dapat digunakan untuk mendukung proses training calon operator kamera televisi. Langkah selanjutnya melakukan pengujian menggunakan sistem pretest dan posttest. Pretest dilakukan sebelum calon operator kamera televisi menggunakan aplikasi mobile learning dan posttest dilakukan setelah menggunakan aplikasi mobile learning. Adapun metode dalam pengumpulan data ditempuh dengan :

\section{a. Interview / wawancara}

Wawancara dilakukan kepada Manajer teknik MMTC TV serta pihak-pihak yang terkait untuk mendapatkan data yang dapat mendukung peneltian.

\section{b. Analisis Perangkat Lunak/Aplikasi}

Menganalisis permasalahan yang muncul dan menentukan spesifikasi kebutuhan sistem yang akan dibuat. Tujuan dari analisis ini adalah mengetahui kebutuhan sistem perangkat lunak yang akan digunakan. Hasil perancangan berupa dokumen Deskripsi Perancangan Perangkat Lunak.

\section{c. Perancangan Lunak/Aplikasi}

Perangkat

Merancang sistem berdasarkan hasil analisis yang sebelumnya telah dilakukan. Perancangan dilakukan untuk mendapatkan deskripsi arsitektural perangkat lunak deskripsi data dan deskripsi prosedural. Hasil perancangan berupa dokumen Deskripsi Perancangan Perangkat Lunak.

\section{d. Pembuatan Perangkat Lunak/Aplikasi}

Pada tahap ini dilakukan pekerjaan pembangunan perangkat lunak berdasarkan analisa dan pemodelan yang telah dilakukan.

\section{e. Pengujian aplikasi}

Pada tahap ini dilakukan proses pengujian aplikasi android untuk menentukan aplikasi android seperti apa yang mampu memberikan tingkat efektivitas dan kemudahan bagi calon operator kamera stasiun televisi yang lebih baik.

\section{f. Rekomendasi aplikasi}

Pada tahap ini dilakukan rekomendasi aplikasi dari hasil pengujian aplikasi yang telah dilakukan.

\section{g. Pengujian Peningkatan Efektivitas Terhadap Objek Yang Diteliti}

Menganalisis efektivitas aplikasi $m$ learning pada anggota baru calon operator kamera stasiun televisi. Dalam hal ini pengujian dilakukan di MMTC TV yang sedang menjalani proses training dengan menggunakan metode Kuisioner. Hasil analisa tersebut kemudian diambil kesimpulan berdasarkan fakta-fakta yang diperoleh.

\section{TINJAUAN PUSTAKA \\ a. Peneliti terdahulu}

Penelitian Prasetyo, et. al (2015) membahas tentang pengaruh penggunaan media pembelajaran kimia berbasis android dalam meningkatkan motivasi belajar siswa SMA. Subjek penelitian adalah SMAN 1 Banguntapan Yogyakarta yang terdiri atas satu kelas eksperimen dan satu kelas kontrol. Pengumpulan data menggunakan angket motivasi belajar dengan skala Likert. Data yang diperoleh dianalisis nilai gain-nya untuk mengetahui peningkatan motivasi belajar siswa SMA. Berdasarkan hasil penelitian yang telah dilakukan dapat disimpulkan bahwa terdapat perbedaan yang signifikan pada peningkatan motivasi belajar siswa SMA, dimana siswa yang menggunakan media pembelajaran berbasis android memiliki peningkatan yang lebih baik.

Hermawan,budi dan Ong Peter Leonardo (2017) meneliti tentang peningkatan efektifitas belajar bahasa mandarin dengan memanfaatkan mobile learning, dalam hal ini peneliti menggunakan aplikasi android untuk melakukan proses pembelajaran. Hasil penelitian menunjukkan hasil yang posotif dimana terjadi peningkatan hasil belajar. Sebelum menggunakan aplikasi mobile learning data yang diperoleh adalah pembelajar awal Bahasa Mandarin dalam 
melafalkan konsonan dasar sebelum menggunakan media pembelajaran mobile learning adalah 454 kesalahan $(36,03 \%)$, setelah menggunakan media pembelajaran mobile learning terjadi penurunan 274 kesalahan $(21,75 \%)$, sehingga selisih prosentase kesalahan $14,29 \%$.

Penelitian sejenis juga dilakukan Nasution, et. al. (2018) tentang pengembangan media pembelajaran aplikasi Buku Saku Digital Komputer berbasis Android. Ujicoba dilakukan di STKIP Tapanuli Selatan oleh 30 siswa dan menunjukkan respon positif karena semua menunjukkan persentase $\geq 70 \%$. Berdasarkan data tersebut dapat disimpulkan bahwa media pembelajaran Aplikasi Komputer dikemas dengan menarik, contoh soal dan soal disampaikan dengan jelas, mendorong rasa ingin tahu dalam belajar Aplikasi Komputer, menambah pemahaman tentang Aplikasi Komputer, dan menambah motivasi dalam belajar Aplikasi Komputer.

\section{b. Mobile learning}

Mobile learning didefinisikan oleh Clark Quinn [Quinn 2000] sebagai : The intersection of mobile computing and $e$ learning: accessible resources wherever you are, strong search capabilities, rich interaction, powerful support for effective learning, and performance-based assessment. ELearning independent of location in time or space.

Berdasarkan definisi tersebut maka
mobile learning merupakan model pembelajaran yang memanfaatkan teknologi informasi dan komunikasi. Konsep pembelajaran tersebut membawa manfaat ketersediaan materi training yang dapat di akses setiap saat disertai visualisasi materi yang menarik. Hal penting yang perlu diperhatikan bahwa tidak setiap materi training cocok memanfaatkan mobile learning. Istilah mobile learning (m-learning) mengacu kepada penggunaan perangkat/divais teknologi informasi (TI) genggam dan bergerak, seperti telepon genggam, Laptop dan tablet PC, dalam pembelajaran. Mobile learning (m-Learning) merupakan bagian dari electronic learning (e-Learning) sehingga, dengan sendirinya, juga merupakan bagian dari distance learning (d-Learning).

c. Kamera

Secara umum ada dua jenis kamera yang digunakan untuk produksi televisi, yakni kamera ENG atau Electonic News Gathering.
Kamera ENG sesuai namanya biasanya digunakan untuk liputan di lapangan atau outdoor. Yang ke dua adalah jenis kamera EFP atau Electronic Field Production, yaitu jenis kamera yang dipeuntukan produksi baik untuk keperluan indoor maupun outdoor serta dapat digunakan sebagai kamera studio, yakni kamera untuk keperluan studio yang biasanya digunakan dengan lokasi indoor.

\section{d. Aperture}

Di kamera televisi disebut juga Iris, yaitu sejumlah lembaran metal tipis yang disusun sedemikian rupa sehingga bisa dibuka dan ditutup untuk mengatur banyaknya sinar yang masuk ke lensa kamera. Iris seperti pupil mata kita yang bisa membesar dan mengecil sesuai cahaya yang masuk. Bila Iris dibuka selebar mungkin, lensa mengirim sinar maksimum ke dalam kamera, sebaliknya kalau bukaan iris dikurangi lubang diafragma akan menyempit, sehingga sinar yang masuk ke kamera jadi sedikit.

\section{e. Shutter speed}

Shutter speed atau kecepatan pengambilan gambar dalam kamera adalah menunjukanwaktu yang diperlukan cahaya untuk terekam pada sensor kamera atau film. Kecepatan rana dan aperture/bukaan diafragma menentukan seberapa banyak cahaya yang dapat terekam pada sensor. Ukuran shutter speed/kecepatan rana biasa diberi nilai $1 / 2000 \mathrm{~s}, 1 / 1000 \mathrm{~s}, 1 / 500 \mathrm{~s}, 1 / 250 \mathrm{~s}$, $1 / 125 \mathrm{~s}, 1 / 60 \mathrm{~s}, 1 / 30 \mathrm{~s}, 1 / 15 \mathrm{~s}, 1 / 8 \mathrm{~s}, 1 / 4 \mathrm{~s}, 1 / 2 \mathrm{~s}$, 1s. Angka 1 berarti shutter membuka dengan kecepatan 1/1 detik. Angka 2000 berarti shutter membuka dengan kecepatan 1/2000 detik, dan seterusnya.

\section{f. Fokus}

Fokus adalah pengaturan lensa yang tepat untuk jarak tertentu. Gambar dikatakan fokus apabila proyeksi gambar yang dihasilkan oleh lensa jatuh di permukaan tabung atau CCD jelas dan tajam. Sehingga nampak juga di viewfinder dan monitor.

\section{g. White balance}

White balance adalah mencari keseimbangan warna putih dari warna dasar red green blue. Perbedaan sumber cahaya akan mengakibatkan warna yang seharusnya putih menjadi berbeda. Rata-rata kamera video telah memiliki fungsi auto white balance (AWB) yang akan secara otomatis mengukur suhu cahaya yang ada dan menyamakannya dengan kamera. Selain itu 
juga, ada opsi - opsi white balance lainnya di kamera seperti: Daylight, Shade, Cloudy, Tungsten, dan White Fluorescent Light

h. Multimedia

Multimedia adalah kombinasi antara teks, grafik, animasi, audio dan video yang bertujuan untuk menyampaikan informasi melalui komputer atau media elektronik lainnya.

\section{HASIL DAN PEMBAHASAN}

Untuk mengetahui aplikasi yang efektif untuk training calon operator kamera televisi maka akan dilakukan pengujian aplikasi android yang berbasis teks dan berbasis audio dengan metode Independent Sample t Test. Dengan pengujian aplikasi tersebut diharapkan dapat diperoleh hasil rekomendasi aplikasi yang dapat digunakan untuk meningkatkan efektifitas training calon operator kamera televisi.

Dari hasil pengujian, aplikasi yang lebih efektif akan digunakan untuk proses training calon operator kamera televisi. Setelah itu tingkat efektifitas training dari calon operator kamera televisi akan diuji dengan metode Paired Sample t Test dengan melakukan uji pretest dan posttest. Uji pretest dilakukan ketika calon operator kamera televisi belum menggunakan aplikasi training berbasis android. Sedangkan posttest dilakukan ketika calon operator kamera televisi sudah menggunakan aplikasi training berbasis android. Hasil yang diperoleh dari pengujian aplikasi didapatkan data sebagai berikut:

\section{Uji Independent Samples t Test}

Sebelum dilakukan uji independent samples $t$ test maka akandilakukan uji normalitas terhadap data yang akan didistribusikan. Berikut adalah tabel hasil uji normalitas sebelum melakukan uji independent samples $t$ test

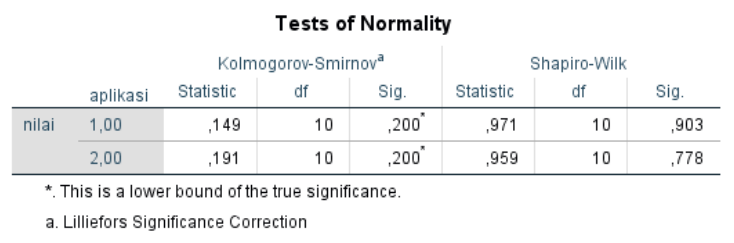

Dapat disimpulkan bahwa nilai sig pada tabel uji kolmogrov-smirnov nilai probabilitas $>0,05$ yaitu $(0,200$ dan 0,200$)$ maka bisa dikatakan distribusi kedua sampel adalah normal, selain itu pada tabel shapiro-wilk nilai probabilitas juga lebih dari 0,05 yaitu $(0,93$ dan 0,778 ) maka dapat dikatakan distribusi kedua sampel adalah normal.

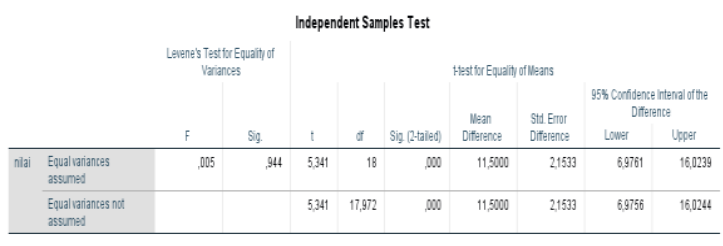

Berdasar hasil pengujian independent samples test dihasilkan nilai $\mathrm{F}$ dengan Equal varience assumed adalah 0,005 dan Probabilitas 0,944. Karena probabilitas $<0,05$ maka Ho ditolak. Dengan demikian dapat disimpulkan bahwa aplikasi berbasis teks memberikan hasil yang lebih signifikan dibandingkan dengan aplikasi berbasis audio.

\section{Group Statistics}

\begin{tabular}{|c|c|c|c|c|c|}
\hline & aplikasi & N & Mean & Std. Deviation & $\begin{array}{l}\text { Std. Error } \\
\text { Mean }\end{array}$ \\
\hline \multirow[t]{2}{*}{ nilai } & teks & 10 & 78,900 & 4,9092 & 1,5524 \\
\hline & audio & 10 & 67,400 & 4,7188 & 1,4922 \\
\hline
\end{tabular}

Berdasarkan nilai mean terdapat perbedaan angka yang menunjukkan aplikasi berbasis teks mempunyai hasil yang lebih tinggi. Karena aplikasi teks lebih signifikan dibandingkan dengan aplikasi berbasis audio maka aplikasi berbasis teks dapat direkomendasikan menjadi aplikasi untuk training calon operator kamera tv.

\section{Uji efektivitas training calon operator tv}

Pretest dilakukan untuk mengetahui nilai / kemampuan calon operator kamera televisi sebelum menggunakan aplikasi training berbasis android. Sedangkan posttest dilakukan untuk mengetahui nilai/kemampuan calon operator kamera setelah menggunakan aplikasi android. Pengujian tingkat efektivitas dengan menggunakan metode uji paired samples $t$ test. Sebelum melakukan pengujian dengan metode paired samples $t$ test maka akan dilakukan uji normalitas terhadap data yang akan didistribusikan. 


\begin{tabular}{|c|c|c|c|c|c|c|c|c|c|}
\hline \multicolumn{10}{|c|}{ Tests of Normality } \\
\hline & \multirow[b]{2}{*}{ VAR00001 } & \multicolumn{4}{|c|}{ Kolmogorov-Smirnov ${ }^{\mathrm{a}}$} & \multicolumn{4}{|c|}{ Shapiro-Wilk } \\
\hline & & 11 Stat & & df & Sig. & Statistic & df & f & $!$ \\
\hline nilai 1 & 1,00 & & 197 & 10 & $200^{n}$ & .899 & & 10 & \\
\hline \multicolumn{10}{|c|}{${ }^{*}$. This is a lower bound of the true significance. } \\
\hline \multicolumn{10}{|c|}{ a. Lilliefors Significance Correction } \\
\hline \multicolumn{10}{|c|}{ Tests of Normality } \\
\hline & & \multicolumn{3}{|c|}{ Kolmogorov-Smirnov ${ }^{\mathrm{a}}$} & \multicolumn{4}{|c|}{ Shapiro-Wilk } & \\
\hline & VAR00001 & Statistic & $\mathrm{df}$ & Sig. & Statistic & df & Sig. & & \\
\hline nilai 2 & 1,00 & 188 & 10 & $200^{\circ}$ & 924 & 10 & .395 & & \\
\hline
\end{tabular}

Data yang diperoleh dari uji normalitas pretest maupun posttest menunjukkan nilai sig pada pretest $>0,05$ yaitu 0,211 sedangkan nilai sig pada posttest juga menunjukkan $>0.05$ yaitu 0.395. Dengan demikian distribusi data bisa dikategorikan normal.

\section{Uji paired samples $t$ test}

Nilai rata-rata pada saat test sebelum di beri aplikasi sebesar 67,00 sedangkan test setelah di beri aplikasi mengalami peningkatan menjadi 77,800 Adanya peningkatan ini dapat diindikasikan bahwa perlakuan yang diberikan efektif.

\begin{tabular}{|c|c|c|c|c|c|}
\hline \multicolumn{6}{|c|}{ Paired Samples Statistics } \\
\hline & & Mean & $\mathrm{N}$ & Std. Deviation & $\begin{array}{l}\text { Std. Error } \\
\text { Mean }\end{array}$ \\
\hline \multirow[t]{2}{*}{ Pair 1} & nilai 1 & 67,0000 & 10 & 5,61743 & 1,77639 \\
\hline & nilai 2 & 77,8000 & 10 & 5,41192 & 1,71140 \\
\hline
\end{tabular}

Untuk mengetahui apakah ada perbedaan yang signifikan sebelum dengan sesudah perlakuan secara statistic, maka dilakukan uji hipotesis.

\begin{tabular}{|c|c|c|c|c|}
\hline \multicolumn{5}{|c|}{ Paired Samples Correlations } \\
\hline & & N & Correlation & Sig. \\
\hline Pair 1 & nilai $1 \&$ nilai 2 & 10 & -270 & .450 \\
\hline
\end{tabular}

Hasil korelasi antara kedua variabel menghasilkan angka $-0,270$, sedangkan nilai sig adalah 0,450. Dengan hasil yang diperoleh nilai probabilitas $>0.05$ sehingga dapat disimpulkan bahwa tidak terdapat korelasi yang sig antara nilai pretest dengan nilai pada saat posttest.

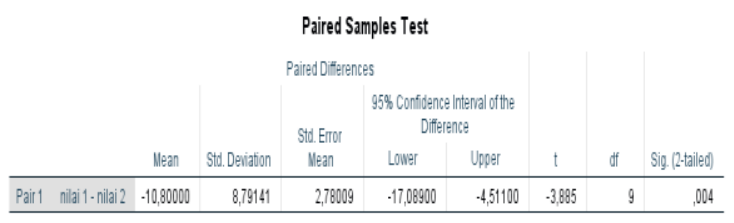

Nilai sig (2-tailed) yang dihasilkan adalah $<0.05$ yaitu 0,004 . Hal ini menunjukkan adanya perbedaan yang signifikan antara pretest dan posttest, dan menunjukkan terdapat pengaruh yang bermakna terhadap perbedaan perlakuan yang diberikan pada masing masing variabel.

\section{KESIMPULAN DAN SARAN}

a. Kesimpulan

1) Bahwa aplikasi training calon operator kamera televisi berbasis android dengan tampilan teks lebih efektif dibandingkan dengan aplikasi training berbasis android yang menampilkan audio.

2) Hasil dari uji pelatihan calon operator kamera televisi berbasis aplikasi android menunjukkan hasil yang signifikan, dimana nilai signifikansi $<0,05$ sehingga hasil pretest dan posttest mengalami perubahan yang signifikan.

3) Berdasarkan statistik deskriptif tes awal (pretest) dan tes akhir (posttest) terbukti tes akhir mempunyai nilai lebih tinggi.

4) Proses training calon operator kamera televisi berbasis aplikasi android dapat meningkatkan efektivitas training.

\section{b. Saran}

1) Berdasarkan hasil kesimpulan maka penulis memberikan saran agar peneliti selanjutnya melakukan pengujian lebih dari dua jenis aplikasi, misalkan aplikasi yang dilengkapi dengan video, gambar atau dengan augmented reality.

2) Peneliti selanjutnya diharapkan mampu mengembangkan aplikasi yang dilengkapi dengan simulasi dan dengan multi bahasa.

\section{REFERENSI}

Ghozali, Imam, 2016, Aplikasi Analisis Multivariete Dengan Program IBM SPSS 23, Universitas Diponegoro, Semarang

Margaret Driscoll, Saul Carliner, 2005, Advanced Web-Based Training Strategies : Unlocking Instructionality sound online learning, Preifer, San Fransisco 
Santoso, singgih, 2018, Menguasai Statistik Dengan SPSS 25, PT Elex Media Komputindo, Jakarta

Thorne, Kaye (2003). Blended Learning: How to integrate online and traditional learning. Kagan Page, london

Fatimah dan Mufti., 2014. Pengembangan Media Pembelajaran Ipa- Fisika Smartphone Berbasis Android sebagai penguat Karakter sains siswa. J.kaunia. vol X No 1, April 2014. ISSN 1829. 2014

Hermawan, Budi dan Ong Peter Leonardo,.2017. Keefektivitasan Penggunaan Media Mobile Learning Dalam Meningkatkan Pelafalan Hanyu Pinyin Bahasa Mandarin. Jurnal Paramasastra p- ISSN 2355-4125. vol. 4 no. 2 tahun 2017

Iqbal, shakeel, et, al., 2017. Mobile Phone Usage and Students' Perception towards M-Learning: A Case of Undergraduate Students in Pakistan. papers.ssrn.com. ISSN: 2292-8588. Vol. 32, No. 1, 2017

Krisnawati dan Supari Muslim., 2016. Pengembangan Media Pembelajaran Mobile Learning Berbasis Android Pada Mata Pelajaran Instalasi Penerangan Listrik Di Smk Negeri 3 Surabaya. Jurnal Pendidikan Teknik Elektro, Volume 05 Nomor 02 Tahun 2016, 557 - 566

Nasution, et. al., 2018, Pengembangan Media Pembelajaran Berbasis Android Matakuliah Aplikasi Komputer Guna Meningkatkan Minat Belajar Mahasiswa. Jurnal Education and development, ISSN.2614-6061 volume 05 No1 edisi juli 2018

Prasetyo, et. Al., 2015, Pengaruh Penggunaan Media Pembelajaran Kimia Berbasis Android Terhadap Peningkatan Motivasi Belajar Siswa Sma. Seminar Nasional Pendidikan Sains. ISSN : 2407-4659 2015

Quinn, C. (2000). M-learning, Mobile Wireless in Your Pocket Learning. Line zine

Vidal, marta, et, al., 2017. Determinants of acceptence of mobile learning as an element of human capital training in organisations. papers.ssrn.com 2018 